\title{
REPRODUCTIVE CAPACITY OF DAIRY BULLS- VI. EFFECT OF UNILATERAL VASECTOMY AND EJACULATION FREQUENCY ON SPERM RESERVES; ASPECTS OF EPIDIDYMAL PHYSIOLOGY*ं
}

\author{
R. P. AMANN AND J. O. ALMQUIST \\ Dairy Breeding Research Center, Department of Dairy Science, \\ Pennsylvania State University, University Park, Pennsylvania, U.S.A.
}

(Received 26th Fune 1961)

\begin{abstract}
Summary. Gonadal and extra-gonadal sperm reserves were determined for nine 36-month-old Holstein bulls 23 weeks after unilateral vasectomy. The postoperative treatment groups, of three bulls each, were subjected to the following regimen: sexual rest, two ejaculates per week, and eight ejaculates per week for the last 20 weeks before slaughter. The correlation between gonadal reserves and testis weight was highly significant, $+0 \cdot 70$. Gonadal reserves averaged $15 \cdot 2 \pm$ $0.8 \times 10^{9}$ and were not affected by either unilateral vasectomy or pre-slaughter ejaculation frequency. Sperm reserves in the caput and corpus epididymis also were unaffected by treatments. Sperm reserves in the cauda epididymis on the intact side were similar in the sexuallyrested and twice-weekly-ejaculated bulls. In bulls ejaculated eight times weekly, the cauda on the intact side contained $24 \%$ fewer spermatozoa just prior to ejaculation than if the bulls had been sexually rested. In eight of the nine bulls, sperm reserves in the cauda epididymis on the vasectomized side averaged $22.0 \times 10^{9}$ spermatozoa as compared to $11.4 \times 10^{9}$ in the contralateral cauda; an average of $17.8 \times 10^{9}$ spermatozoa accumulated in the ductus deferens just proximal to the site of vasectomy. In the other bull, the cauda epididymis on the vasectomized side contained $77.4 \times 10^{9}$ spermatozoa but there was no accumulation in the ductus deferens. After 23 weeks, some spermatozoa were found distal to the site of ligation in all nine bulls.

There appears to be a reciprocal relationship between sperm resorption and the total number of spermatozoa removed by collection and masturbation. The apparent rate of sperm resorption in the epididymis on the intact side of three bulls collected eight times weekly was $57 \%$. In the vasectomized sides of nine bulls, it was greater than $96 \%$. The rate of sperm resorption was postulated to be dependent upon the number of spermatozoa present in the cauda epididymis.
\end{abstract}

* Authorized for publication on 19th June 1961, as Paper No. 2569 in the journal series of the Pennsylvania Agricultural Experiment Station.

$\dagger$ A portion of the data contained in this paper is from a thesis submitted by the senior author to the Graduate School of The Pennsylvania State University in partial fulfillment of the requirements for the degree of Doctor of Philosophy. 


\section{INTRODUGTION}

The recent report by Almquist \& Amann (1961) showed that the extragonadal sperm reserves (EGR) of mature bulls averaged $73 \times 10^{9}$. In sexually rested bulls, about $54 \%$ of these spermatozoa were in the cauda epididymis. These workers found that sperm reserves were altered by ejaculation. In mature bulls, regular collection at six or seven ejaculates per week resulted in a $25 \%$ reduction of the sperm content of the cauda epididymis just prior to ejaculation. Following a twenty-ejaculate depletion of previously sexually rested bulls the total EGR was reduced by $53 \%$. The effect of vasectomy on EGR is unknown. Literature on EGR was reviewed by Almquist \& Amann (1961).

Simeone \& Young (1931) discussed the various means by which nonejaculated spermatozoa might be eliminated. They concluded that death, liquefaction, and resorption of guinea-pig spermatozoa occurred primarily in the ductus deferens. Since then, many workers have suggested that spermatozoa are resorbed in the ductus deferens or epididymis (Bayle \& Gouygou, 1951; Glover, 1959, 1960; Grant, 1958; Kennelly, 1960; Macmillan, 1954; Reid \& Cleland, 1957). Neither the magnitude of sperm resorption nor its relation to sperm production and epididymal reserves has been elucidated. For bulls, Amann (1962) recently demonstrated that sexual rest, collection of semen at low or high frequencies, and unilateral vasectomy did not affect spermatogenesis. Consequently, non-ejaculated spermatozoa must be removed from the reproductive system by masturbation, passage in the urine, or resorption in the excurrent ducts. In vasectomized bulls, only the latter mode could be operative. Thus, in such bulls, the EGR at slaughter should equal the total number of spermatozoa produced postoperatively less any spermatozoa resorbed proximal to the site of ligation.

The data in this report are from the same bulls used by Amann (1962) for quantitative studies on spermatogenesis. The daily sperm output and semen characteristics before and after unilateral vasectomy of these bulls were reported by Amann \& Almquist (1961b). The present report concerns EGR and sperm resorption in vasectomized bulls collected at various ejaculation frequencies.

\section{MATERIALS AND METHODS}

Gonadal and extra-gonadal sperm reserves of nine unilaterally vasectomized Holstein bulls were determined 23 weeks after surgery with the technique of Amann \& Almquist (1961a). The pre- and postoperative treatment of these bulls has been described (Amann, 1962; Amann \& Almquist, 1961b). In brief, they were collected at six ejaculates per week $(6 \times)$ for 5 weeks before surgery. At the time of vasectomy, about $1 \mathrm{~cm}$ of ductus deferens was removed and both exposed ends were ligated with nylon suture material. The site of vasectomy was about $25 \mathrm{~cm}$ from the cauda epididymis-ductus deferens junction. Following a 3-week recuperation, the bulls were placed in one of three treatment groups. Three bulls were sexually rested (SR), two for 23 weeks and one for 11 weeks prior to slaughter. Three bulls were ejaculated twice per week $(2 \times)$ and three were ejaculated eight times per week $(8 \times)$. During this 20 -week experimental collection period, daily sperm output averaged $1.43 \times 10^{9}$ 
for $2 \times$ bulls and $2 \cdot 17 \times 10^{9}$ for $8 \times$ bulls (Amann \& Almquist, 1961b). One ejaculate was collected from the $2 \times$ bulls and two ejaculates from the $8 \times$ bulls about 60 to $90 \mathrm{~min}$ before slaughter.

\section{RESULTS AND INTERPRETATION}

At slaughter, the testis on the intact side of the reproductive system was heavier in five bulls, but the difference for all nine bulls averaged only $7 \mathrm{~g}$. The largest difference in testicular weight was $15 \%$ for an SR bull. Although all nine bulls were similar in age ( 36 months), testis weight ranged from 250 to 356 g. Paired-testes weight also was not significantly correlated with body weight. Certain gross changes in the excurrent ducts were evident. The testes and epididymides from a typical bull (on $2 \times$ ) are shown in Pl. 1, Figs. 1 and 2; the cauda epididymis was slightly enlarged. A marked dilation of the ductus deferens just proximal to the site of vasectomy, accompanied by proliferation of connective tissue, was found in seven of the nine bulls. This area contained large numbers of spermatozoa. Of the other two bulls, one (Bull 169 on $8 \times$ ) had a very large cauda epididymis (Pl. 1, Fig. 3), but no accumulation of spermatozoa at the site of vasectomy. The other bull (on $2 \times$ ) had only a small sperm accumulation near the ligation, although there appeared to be an accumulation of spermatozoa in the ductus deferens near its junction with the cauda epididymis (Pl. 1, Fig. 4). The epididymides on the vasectomized side averaged $10.7 \mathrm{~g}$ heavier $(37 \%)$ than those on the intact side (Table 1). With the exception of Bull 169 (see above), this difference ranged from 0.5 to $13.3 \mathrm{~g}$. In Bull 169 , the epididymis on the vasectomized side weighed $64.0 \mathrm{~g}$ as compared to $26.4 \mathrm{~g}$ on the intact side.

Individual testis sperm counts ranged from 9.4 to $19.6 \times 10^{9}$ (Table 1) and were highly significantly correlated to testis weight $(+0 \cdot 70)$. The sixteen testes (counts were not made for one SR bull) averaged 15.2 $\pm 0.8 \times 10^{9}$ spermatozoa or $52 \cdot 1 \pm 2.0 \times 10^{6}$ spermatozoa per gramme of testis. Testes of $8 \times$ bulls averaged $5 \cdot 7 \times 10^{6}$ spermatozoa per gramme less than those of SR and $2 \times$ bulls. However, based on testis sperm counts it appeared that ejaculation frequency and unilateral vasectomy did not affect spermatogenesis. This conclusion was verified by histological studies (Amann, 1962).

The total EGR on the vasectomized sides averaged $55.5 \times 10^{9}$ as contrasted to $23.5 \times 10^{9}$ for the intact sides. Regardless of ejaculation frequency and vasectomy, the numbers of spermatozoa in the caput $\left(7 \cdot 1 \pm 0.5 \times 10^{9}\right)$ and in the corpus $\left(1.6 \pm 0.2 \times 10^{9}\right)$ of the eighteen epididymides were similar. On the vasectomized side, however, the cauda epididymis in SR bulls contained an average of $28 \cdot 1 \times 10^{9}$ spermatozoa; about twice as many as in the contralateral cauda. The magnitude of this build-up varied greatly among the nine bulls. In one bull, there was a difference of only $0.8 \times 10^{9}$ spermatozoa between the two cauda whereas in Bull 169 this difference was $68.8 \times 10^{9}$ spermatozoa. When the latter bull was excluded, the eight cauda on the intact and vasectomized sides averaged 11.4 and $22.0 \times 10^{9}$ spermatozoa.

Disregarding Bull 169, which showed no accumulation of spermatozoa, the number of spermatozoa just proximal to the site of vasectomy ranged from 5.4 to $42.7 \times 10^{9}$. Eight bulls averaged $17.8 \pm 4.3 \times 10^{9}$ spermatozoa. The 
PL.ATE I
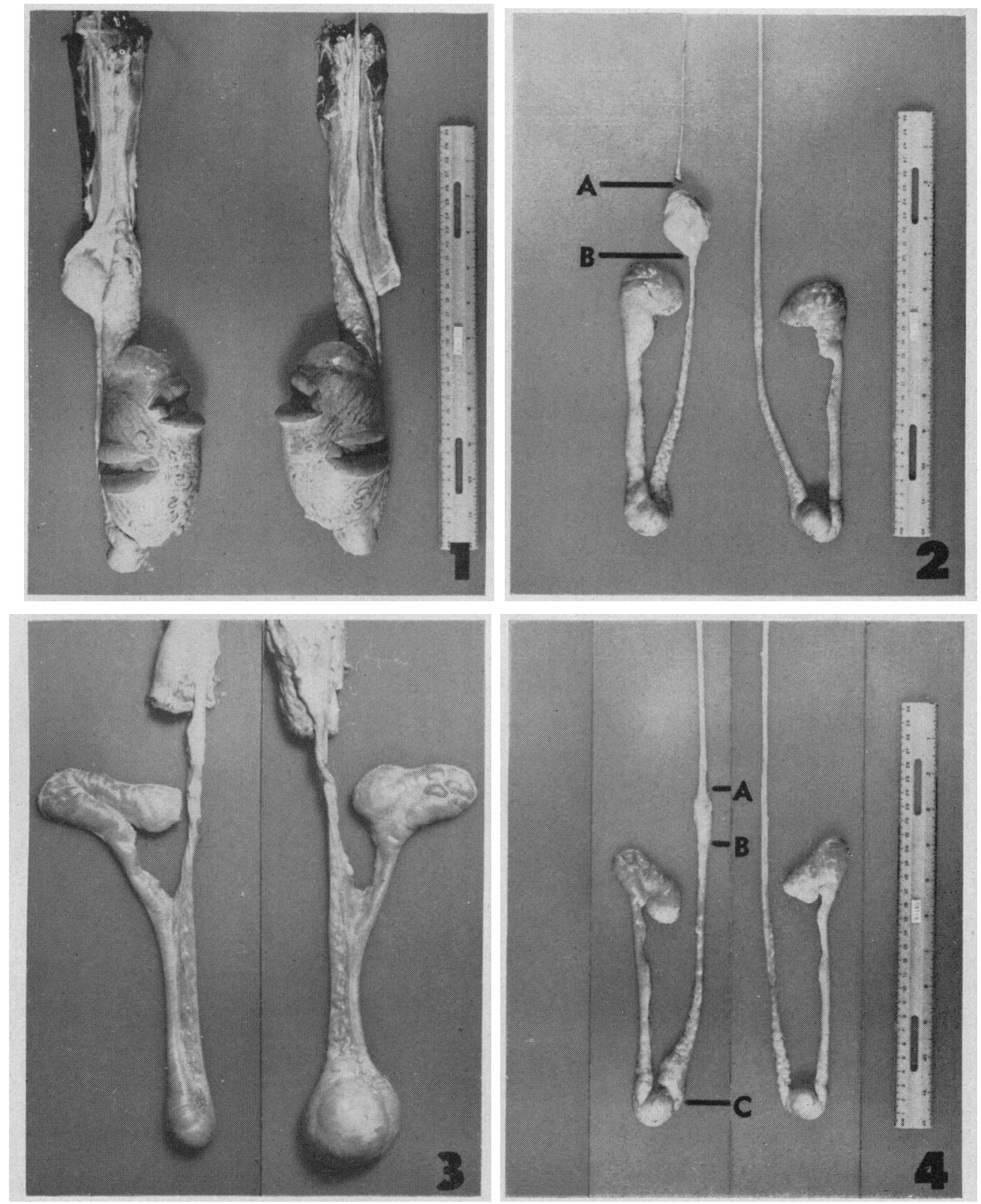

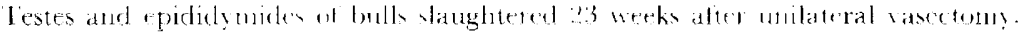

Fic. 1. Typical enlargement of ductus deferens left, al the site of vasectomy associated with sperm accumulation $!$

Fic. 2. Epididymides shown in Fig. I atter dissection trom the testes. Indicated are: $A$, the site of vasectom, $I$ to B. accumulation of spermatozoa at the site of rasectoms $\frac{1}{3}$.

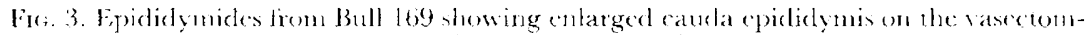
iacd side eright: Nene absenee of enlargement at the site of vasectomy a

Fig. 4. Epididymides from a bull with essentially no enlargenent of the ductus deferens at the site of vasectomy $A$ 10 B). There was some enlargement associated with accumulation of spermatozoa in the proximal ductus deferens $(C, \quad \therefore b)$. 
number of spermatozoa in this area was not correlated with the sperm content of the cauda epididymis. Gross examination suggested that shortly after vasectomy spermatozoa had accumulated at the proximal ligation forming a spermatocoele which eventually was encapsulated with connective tissue. It was impossible to ascertain if rupture of the ductus deferens and extravasation of spermatozoa occurred. At the time of slaughter, spermatozoa isolated in this region varied from a slightly viscous, normal sperm suspension to a firm rubbery mass. The spermatozoa could be dispersed readily in $0.9 \%$ sodiumchloride solution.

TABLE 1

SPERM RESERVES 23 WEEKS AFTER UNILATERAL VASEGTOMY

\begin{tabular}{|c|c|c|c|c|c|c|c|c|}
\hline \multirow{2}{*}{ Portion of tract } & \multicolumn{2}{|c|}{$\begin{array}{c}\text { SR for } \\
23 \text { weeks }\end{array}$} & \multicolumn{2}{|c|}{$\begin{array}{l}2 \times \text { for } \\
\text { last } 20 \text { weeks }\end{array}$} & \multicolumn{2}{|c|}{$\begin{array}{c}8 \times \text { for } \\
\text { last } 20 \text { weeks }\end{array}$} & \multicolumn{2}{|c|}{ Average } \\
\hline & Intact & Vasect. & Intact & Vasect. & Intact & Vasect. & Intact & Vasect. \\
\hline $\begin{array}{l}\text { Age at slaughter } \\
\text { (months) } \\
\text { Body weight (lb) }\end{array}$ & $\begin{array}{r}34 \\
1,780\end{array}$ & & $\begin{array}{r}35 \\
1,810\end{array}$ & & $\begin{array}{r}36 \\
1,850\end{array}$ & & $\begin{array}{r}35 \\
1,810\end{array}$ & \\
\hline $\begin{array}{l}\text { Testis } \\
\text { Weight }(\mathrm{g}) \\
\text { Total spermatozoa } \\
\text { Spermatozoa/ } \\
\text { gramme }\left(\times 10^{6}\right)\end{array}$ & $\begin{array}{l}307 \\
16 \cdot 2 * \\
53 \cdot 2 *\end{array}$ & $\begin{array}{l}296 \\
16 \cdot 8 * \\
57 \cdot 5 *\end{array}$ & $\begin{array}{r}287 \\
15 \cdot 6 \\
53 \cdot 6\end{array}$ & $\begin{array}{r}286 \\
15 \cdot 6 \\
53 \cdot 6\end{array}$ & $\begin{array}{r}294 \\
14 \cdot 5 \\
\\
49 \cdot 4\end{array}$ & $\begin{array}{r}286 \\
13 \cdot 6 \\
47 \cdot 7\end{array}$ & $\begin{array}{r}296 \\
15 \cdot 3 \\
\\
51 \cdot 9\end{array}$ & $\begin{array}{r}289 \\
15 \cdot 1 \\
52 \cdot 4\end{array}$ \\
\hline $\begin{array}{l}\text { Epididymis } \\
\text { Weight (g) } \\
\text { Caput } \\
\text { Corpus } \\
\text { Cauda } \\
\text { Total }\end{array}$ & $\begin{array}{r}30 \cdot 7 \\
8 \cdot 1 \\
1 \cdot 3 \\
14 \cdot 8 \\
24 \cdot 2\end{array}$ & $\begin{array}{r}36 \cdot 5 \\
7 \cdot 3 \\
1 \cdot 9 \\
28 \cdot 1 \\
37 \cdot 2\end{array}$ & $\begin{array}{r}27 \cdot 6 \\
7 \cdot 1 \\
1 \cdot 3 \\
10 \cdot 8 \\
19 \cdot 2\end{array}$ & $\begin{array}{r}36 \cdot 6 \\
6 \cdot 5 \\
1 \cdot 1 \\
20 \cdot 4 \\
28 \cdot 0\end{array}$ & $\begin{array}{r}28 \cdot 4 \\
7 \cdot 0 \\
2 \cdot 6 \\
7 \cdot 8 \\
17 \cdot 4\end{array}$ & $\begin{array}{c}45 \cdot 5 \\
6 \cdot 8 \\
1 \cdot 3 \\
36 \cdot 0 \dagger \\
44 \cdot 1\end{array}$ & $\begin{array}{r}28 \cdot 9 \\
7 \cdot 4 \\
1 \cdot 7 \\
11 \cdot 1 \\
20 \cdot 3\end{array}$ & $\begin{array}{r}39 \cdot 6 \\
6 \cdot 9 \\
1 \cdot 4 \\
28 \cdot 2 \\
36 \cdot 5\end{array}$ \\
\hline $\begin{array}{l}\text { Ductus deferens } \\
\text { Proximal } 25 \mathrm{~cm} \\
\text { At site of vasect. } \\
\text { Distal } \\
\text { Total }\end{array}$ & $\frac{\overline{-}}{\overline{0} \cdot 4}$ & $\begin{array}{c}3 \cdot 0 \\
12 \cdot 6 \\
0 \cdot 02 \\
15 \cdot 6\end{array}$ & $\begin{array}{l}\overline{-} \\
\overline{0} \cdot 3\end{array}$ & $\begin{array}{c}4 \cdot 1 \\
24 \cdot 4 \\
0 \cdot 01 \\
28 \cdot 6\end{array}$ & $\begin{array}{l}\overline{-} \\
\overline{0 \cdot 3}\end{array}$ & $\begin{array}{c}1 \cdot 9 \\
10 \cdot 3 \dagger \\
0 \cdot 01 \\
12 \cdot 2\end{array}$ & $\begin{array}{l}\overline{-} \\
\overline{0} \cdot 4\end{array}$ & $\begin{array}{c}3 \cdot 0 \\
15 \cdot 8 \\
0 \cdot 01 \\
18 \cdot 8\end{array}$ \\
\hline $\begin{array}{l}\text { Ampulla } \\
\text { Ejaculated pre- } \\
\text { slaughter } \\
\text { Total extra-gonadal }\end{array}$ & $\begin{array}{r}0 \cdot 8 \\
\text { none } \\
25 \cdot 4\end{array}$ & $\begin{array}{l}0 \cdot 2 \\
\overline{53 \cdot 1}\end{array}$ & $\begin{array}{r}2 \cdot 9 \\
23 \cdot 1\end{array}$ & $\begin{array}{l}0 \cdot 4 \\
\overline{57 \cdot 0}\end{array}$ & $\begin{array}{r}1 \cdot 3 \\
3 \cdot 2 \\
22 \cdot 2\end{array}$ & $\begin{array}{l}0 \cdot 1 \\
\overline{56 \cdot 4}\end{array}$ & $\begin{array}{r}0.9 \\
\\
2 \cdot 0 \\
23 \cdot 5\end{array}$ & $\begin{array}{c}0 \cdot 3 \\
\overline{55 \cdot 5}\end{array}$ \\
\hline
\end{tabular}

Each value is the average number of spermatozoa $\times 10^{9}$ per side for three bulls.

* Average for two testes.

$\dagger$ One of the three bulls in this group had essentially no accumulation of sperm at site of vasectomy, but had a larger accumulation of sperm in the cauda epididymis.

Necroscopy confirmed that it was impossible for the spermatozoa found distal to the ligations to have come from the proximal ductus deferens. Therefore, an average of $10 \times 10^{6}$ spermatozoa in the distal portion of the ductus deferens (about $60 \mathrm{~cm}$ ) and $252 \times 10^{6}$ spermatozoa in the ampulla remained after 23 weeks. Although unlikely, some of these spermatozoa may have been forced back from the intact side of the tract via the pelvic urethra.

The EGR of the intact sides appeared to be inversely related to ejaculation frequency. However, the differences were small and individual values ranged from 13.2 to $31.2 \times 10^{9}$ spermatozoa. The cauda epididymis on the intact 
side of the SR, $2 \times$ and $8 \times$ bulls contained an average of $14 \cdot 8,10 \cdot 8$ and $7 \cdot 8 \times$ $10^{9}$ spermatozoa, respectively. These values represent the low point in the cyclic partial depletion of the cauda epididymis for $2 \times$ and $8 \times$ bulls that were ejaculated before slaughter (Amann \& Almquist, 1961b). Summation of the number of spermatozoa contained in the ejaculated semen and the ampulla, ductus deferens, and cauda epididymis should give an accurate estimate of the high point in the cyclic pattern of sperm numbers in the distal part of the excurrent ducts of ejaculated bulls. Calculated in this manner, the respective values for the SR, $2 \times$ and $8 \times$ bulls were $16 \cdot 0,14 \cdot 6$ and $12.6 \times 10^{9}$ spermatozoa. These values suggest a decrease of $22 \%$ in $8 \times$ bulls and $9 \%$ in $2 \times$ bulls as compared with the SR bulls.

Bull variation also must be considered for an accurate evaluation of the effect of ejaculation frequency on the number of spermatozoa in the distal portion of the excurrent duct. This correction can be accomplished by using the number of spermatozoa in the caput and corpus epididymis as a base for calculating the relative distribution in the remainder of the tract. The combined number of spermatozoa in the caput and corpus epididymis from the intact side averaged $9.4,8.4$ and $9.6 \times 10^{9}$ for the SR, $2 \times$ and $8 \times$ bulls, respectively. The correction was made for each bull by dividing the total number of spermatozoa in the caput and corpus epididymis into the total number of spermatozoa contained in the cauda epididymis, ductus deferens, ampulla, and ejaculated semen. For the SR, $2 \times$ and $8 \times$ bulls, the values obtained averaged 170,174 and $131 \%$, respectively. This indicates that there was a reduction of $24 \%$ or $4.1 \times 10^{9}$ spermatozoa in the distal part of the excurrent duct system of $8 \times$ bulls just prior to ejaculation as compared with its content if these bulls had been sexually rested. Most of this difference was associated with a reduction in the sperm content of the cauda epididymis (Table 1). Collection at $2 \times$ had no effect on the sperm content of the cauda epididymis.

\section{DISCUSSION}

The relative distribution of the extra-gonadal sperm reserves (EGR) on the intact sides of these 36-month-old bulls was similar to values previously reported (Almquist \& Amann, 1961; Ortavant, 1959). In mature bulls, collection of six to eight ejaculates weekly reduced the sperm content of the cauda epididymis just prior to ejaculation by 25\% (Almquist \& Amann, 1961). The present data for young bulls confirm this finding. They also show that collection of one ejaculate each Monday and Friday $(2 \times)$ does not alter sperm numbers in the cauda epididymis prior to ejaculation as compared with its content had the bulls been sexually rested. Ejaculation frequencies of $0,2 \times$ and $8 \times$ per week did not affect the sperm content of the caput and corpus epididymis. Thus, ejaculated spermatozoa probably do not come directly from these latter areas.

Gonadal sperm reserves represent about 3.27 days' production of spermatozoa by a bull (Amann, 1961a). With the average of the two values calculated for each testis from the sperm-count data and from histological data (Amann, 1962), it was estimated that the testicular production for the nine bulls in the present study averaged $10.5 \times 10^{9}$ spermatozoa per day (Amann, 1961a). 
During pre-operative collection at $6 \times$, the daily sperm output for eight of the nine bulls (one was not collected before vasectomy) averaged $4.85 \times 10^{9}$ (Amann \& Almquist, 1961b). Thus, only $43 \%$ of the testicular production was collected at this frequency. Limited data suggest that even by collection of one, two or ten ejaculates daily, only about $50 \%$ of the testicular sperm production can be collected (Amann, 1961a; Hale \& Almquist, 1960). Since relatively few spermatozoa appear to be lost in the urine (Koefoed-Johnsen, 1958; Simeone \& Young, 1931), the remaining spermatozoa must be lost during the collection process, eliminated by masturbation, or resorbed in the excurrent ducts.

In the vasectomized side of the reproductive system, elimination of spermatozoa could occur only by resorption. During the 23 weeks between vasectomy and slaughter, the testis on the vasectomized side produced approximately $845 \times 10^{9}$ spermatozoa. Only $55 \times 10^{9}$ spermatozoa were found proximal to the ligation at the time of slaughter. Since about $25 \times 10^{9}$ of these spermatozoa were present at the time of vasectomy, more than $96 \%$ of the spermatozoa produced disappeared proximal to the ligation. Thus, depending upon collection frequency, it appears that between 50 and $100 \%$ of the spermatozoa produced by the testes are resorbed in the excurrent ducts.

Data for the three unilaterally vasectomized bulls collected at $8 \times$ also suggest a variable rate of sperm resorption. During the first week on $8 \times$ a total of 28.5 $\times 10^{9}$ spermatozoa were obtained. The next 19 weeks, an average of only $15 \cdot 2 \times 10^{9}$ spermatozoa per week was collected. Part of this difference of 13.3 $\times 10^{9}$ spermatozoa can be attributed to spermatozoa from the EGR. However, the total reserves in the cauda epididymis at sexual rest were 14 to $15 \times 10^{9}$ spermatozoa. At slaughter (after ejaculation of $3.2 \times 10^{9}$ spermatozoa), the cauda still contained $7.8 \times 10^{9}$ spermatozoa. Thus, although they initially came from the cauda epididymis, it is apparent that most of these 13.3 $\times 10^{9}$ spermatozoa were replaced by spermatozoa in excess to those ejaculated. Since the daily sperm-production rate was not affected by ejaculation frequency (Amann, 1962), it must be concluded that the rate of sperm resorption was decreased during the first 8 to 10 days on $8 \times$.

For mature bulls with a testicular production of about $13 \times 10^{9}$ spermatozoa daily, Almquist \& Amann (1961) found that $38 \times 10^{9}$ spermatozoa or $53 \%$ of the EGR was removed in a twenty-ejaculate depletion trial. If sperm resorption does not occur it should take about 3 days at sexual rest following depletion to restore the EGR to $73 \times 10^{9}$. However, replenishment requires about 7 days (Boyd \& VanDemark, 1957; Hale \& Almquist, 1960). Apparently a little less than $50 \%$ of the testicular sperm production contributes to restoration of EGR. It is postulated that, following depletion, the net rate of replenishment of the EGR (during sexual rest) is curvilinear. Because the rate of sperm resorption apparently varies with the EGR, the net increase in EGR should be greater the first 2 or 3 days on sexual rest following depletion than on subsequent days.

Simeone \& Young (1931) suggested that resorption of non-ejaculated guinea-pig spermatozoa occurred in the ductus deferens. The present data suggests that the ductus deferens (exclusive of the ampulla) is not a major 
site of sperm resorption in bulls. Spermatozoa were found distal to the site of vasectomy in all nine bulls. Although few in number, it is unlikely that these spermatozoa would have remained 23 weeks in an area of active sperm dissolution. Additional evidence is provided by unpublished data from this Station for one ram and four bulls in which the entire length of one ductus deferens was isolated in situ without disturbing the vascular network. At slaughter 3 to 12 weeks later, counts showed no decrease in the sperm content when compared with the contralateral ductus deferens. In two other rams, there was a $50 \%$ decrease in sperm numbers but the vascular supply to the ductus deferens may have been disturbed.

It is obvious that large numbers of spermatozoa are resorbed in the epididymis. However, studies by Glover (1959, 1960), Kirillov \& Morozov (1936), and Macmillan (1954) showed that following isolation of portions of the epididymis the resorption of spermatozoa is not complete even after many weeks. Unfortunately, these investigations were not quantitative. Preliminary data have been obtained at this Station on sperm resorption in the corpus and cauda epididymis after isolation of these areas by ligature or electrocautery. The number of spermatozoa (based on post-slaughter counts) was reduced about $50 \%$ in the corpus and 50 to $75 \%$ in the cauda epididymis 3 to 12 weeks after isolation. The sperm content of the caput epididymis increased up to $400 \%$. Based on testis sperm counts, even this increase represented only a small fraction of the spermatozoa apparently produced. Although the caput epididymis appears capable of resorbing almost all of the testicular production under certain conditions, it is unlikely that this is the major site of sperm resorption in intact bulls.

The observation of peristaltic contractions of the caput and corpus epididymis (Risley, personal communication, 1959; Risley, 1960; Cross, 1959) and data on the morphology of spermatozoa in the epididymis (Almquist \& Amann, 1962) suggest that spermatozoa are continually moving into the cauda epididymis. Thus, all of the sperm production is not resorbed in the caput and corpus. For rats, Macmillan (1954) concluded that spermatozoa from the corpus passed into the cauda epididymis where they were slowly resorbed.

The available data indicate that the cauda (and perhaps the corpus) epididymis is the major site of physiological sperm resorption. The mode of sperm resorption in the epididymis remains unknown. The absence of partially degenerate (other than tailless) spermatozoa in the excurrent ducts indicates that disappearance of individual spermatozoa is very rapid. However, since the overall rate of sperm resorption is variable and appears to be rather slow in the isolated corpus or cauda epididymis, the rate of sperm resorption apparently is directly related to the number of spermatozoa in the epididymis. If disappearance of spermatozoa resulted from an intrinsic factor or a substance liberated into the tubule lumen, it is unlikely that the rate of sperm resorption would vary in this manner.

Recognition of the high and variable rate of sperm resorption in the epididymis leads to consideration of the epididymis as a physiologically dynamic organ even in its sperm-storage function. Although partially theoretical, the kinetics of sperm production, storage, and resorption in mature bulls are 
illustrated in Text-fig. 1. Daily sperm production (Amann, 1961a), daily sperm output at high ejaculation frequencies (Hale \& Almquist, 1960), and sperm reserves in the cauda epididymis at sexual rest and after high frequency collection (Almquist \& Amann, 1961) have been reported. Sperm reserves in the cauda epididymis during the preliminary stabilization period were extrapolated from known values while sperm-resorption values were determined essentially by difference. Daily sperm production $\left(13 \times 10^{9}\right)$ is constant. The high daily sperm output during the first 2 or 3 days of twicedaily collection results in a drastic reduction in caudal sperm reserves and an accompanying decrease in the rate of sperm resorption. For simplicity, sperm

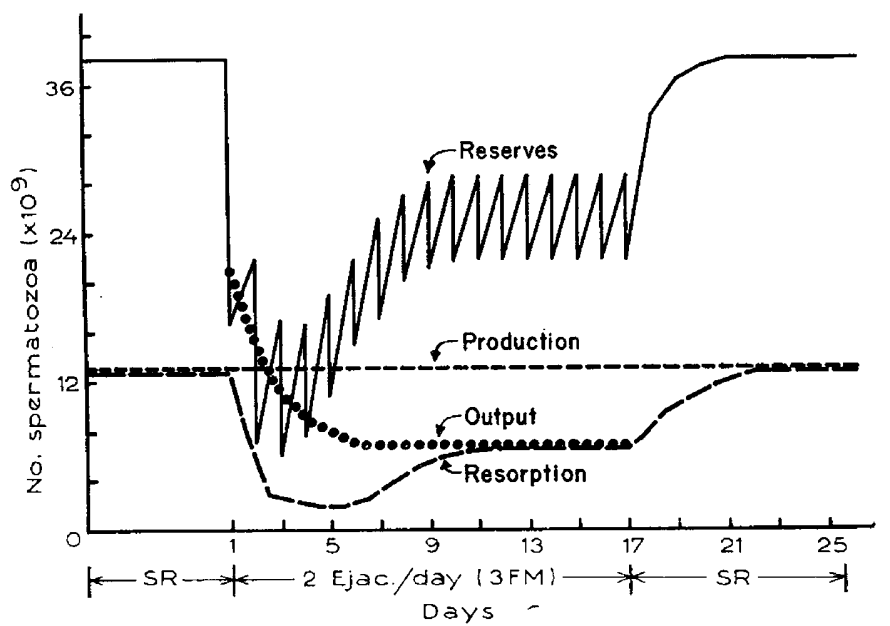

TEXT-FIG. 1. Theoretical relationships among testicular sperm production, sperm output, sperm resorption in the cauda epididymis, and sperm reserves in the cauda epididymis during sexual rest (SR) and collection of two ejaculates (with three false mounts prior to ejaculation) per day.

resorption has been depicted as occurring entirely in the cauda epididymis. As sperm reserves in the cauda epididymis diminish, fewer spermatozoa are available for ejaculation even though there is a partial restoration of reserves during the $24 \mathrm{hr}$ between twice-daily collections. Thus, daily sperm output decreases. After 3 or 4 days, the rate of resorption has decreased to a point where the total number of spermatozoa removed by resorption and ejaculation is less than the $13 \times 10^{9}$ daily production. This leads to a gradual replenishment of the caudal reserves. Since EGR and sperm resorption appear to be directly related, the increase in caudal reserves results in an increase in the rate of sperm resorption. After 8 to 10 days, the rates of sperm production, sperm resorption, and sperm output have become stabilized; caudal sperm reserves are established at a new equilibrium level. This new equilibrium level of caudal reserves is about $25 \%$ below the value at sexual rest. Following cessation of twice-daily collections, the EGR rapidly increases and the rate of sperm resorption increases. After stabilization at sexual rest, essentially the entire testicular sperm production is removed by resorption. Unfortunately, many details of this working hypothesis must await verification. 


\section{ACKNOWLEDGMENTS}

The authors wish to acknowledge the assistance of Drs R. Smith and J. F. Hokanson with the surgery and the technical assistance of Messrs R. G. Saacke, G. R. Howe, and E. W. Wickersham. These studies were supported in part by a grant from The Pennsylvania Association of Artificial Breeding Cooperatives.

\section{REFERENCES}

Almquist, J. O. \& Amann, R. P. (1961) Reproductive capacity of dairy bulls. II. Gonadal and extra-gonadal sperm reserves as determined by direct counts and depletion trials; dimensions and weight of genitalia. 7. Dairy Sci. 44, 1668.

Almouist, J. O. \& Amann, R. P. (1962) Reproductive capacity of dairy bulls. VII. Morphology of sperm in the epididymis. 7. Dairy Sci. (in press).

Amann, R. P. (1961a) Reproductive physiology of the male bovine. Ph.D. Thesis, Pennsylvania State University.

Amann, R. P. (1962) Reproductive capacity of dairy bulls. III. The effect of ejaculation frequency, unilateral vasectomy, and age on spermatogenesis. Amer. $\mathcal{7}$. Anat. 110 (1), (in press).

Amann, R. P. \& Almeurst, J. O. (1961a) Reproductive capacity of dairy bulls. I. Technique for direct measurement of gonadal and extra-gonadal sperm reserves. F. Dairy Sci. 44, 1537.

Amann, R. P. \& Almquist, J. O. (1961b) Reproductive capacity of dairy bulls. V. Detection of testicular deficiencies and requirements for experimentally evaluating testis function from semen characteristics. 7. Dairy Sci. 44, 2283.

Bayle, H. \& Gouygou, C. (1951) Stérilité masculine spermatogénèse et spermatophagie. Presse Medicale, 59, 87.

Boyd, L. J. \& VANDemark, N. L. (1957) Spermatogenic capacity of the male bovine. I. A measurement technique. 7. Dairy Sci. 40, 689.

CRoss, B. A. (1959) Hypothalamic influences on sperm transport in the male and female genital tract. Recent Progress in the Endocrinology of Reproduction, p. 167. Ed. C. W. Lloyd. Academic Press, New York.

Glover, T. D. (1959) Experimental cryptorchidism in rabbits; the response of spermatozoa in the tail of the epididymis. F. Endocrin. 18, x.

Glover, T. D. (1960) Spermatozoa from the isolated cauda epididymis of rabbits and some effects of artificial cryptorchidism. F. Reprod. Fertil. 1, 121.

Granr, J. H. (1958) The passage of trypan blue through the epididymis and its uptake by this organ. Proc. Soc. Situdy Fertil. 10, 95.

HALE, E. B. \& Almquist, J. O. (1960) Relation of sexual behavior to germ cell output in farm animals. 7. Dairy Sci. 43, Suppl., 145.

Kennelly, J. J. (1960) Spermatogenesis in boars. I. The testicular and epididymal spermatozoan reserves. II. Estimated potential daily production of spermatoza. M.S. Thesis, Cornell University.

Kirillov, V. S. \& Morozov, V. A. (1936) Prodol žiteljnostj sohranenija žiznesposobnosti spermatozoidor byka $v$ izolirovannyh ot semennika pridatkah (Duration and survival of bull spermatozoa in an epididymis isolated from the testis). Usp zooteh. Nauk. 2, 19. Citation from Anim. Breed. Abstr. (1937) 5, 22.

KOEFOED-JoHNSEN, H. H. (1958) Undersogelser over saeddannelsen (Investigations on sperm formation). Den kongelige Veterinaer og Landbhøjskole Institut for Sterilitetsforskning Aarsberetning. p. 18. Copenhagen.

Macmillan, E. W. (1954) Observations on the isolated vaso-epididymal loop and on the effects of experimental subcapital epididymal obstructions. Proc. Soc. Study Fertil. 6, 57.

Ortavant, R. (1959) Spermatogenesis and morphology of the spermatozoon. Reproduction in Domestic Animals, Vol. 2, chap. 1. Ed. H. H. Cole \& P. T. Cupps. Academic Press, New York.

Rerd, B. L. \& Gleland, K. W. (1957) The structure and function of the epididymis. I. The histology of the rat epididymis. Aust. F. Zool. 5, 223.

Risley, P. L. (1960) Histochemical distribution of cholinesterases in the rat epididymis: neural, muscular, and epithelial reactions. Anat. Rec. 136, 266 (Abstr.).

Simeone, F. A. \& Young, W. C. (1931) A study of the function of the epididymis. IV. The fate of nonejaculated spermatozoa in the genital tract of the male guinea pig. 7. exp. Biol. 8, 163. 